Archived version from NCDOCKS Institutional Repository http://libres.uncg.edu/ir/asu/

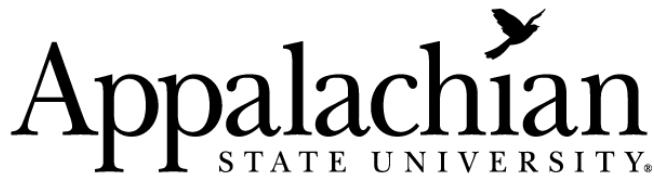

B O O N E, N O R T H C A R O L I N A

\section{Incentives In The Temporary Assistance For Needy Families Program: A Review Of The Literature}

\author{
By: Leah Hamilton
}

\begin{abstract}
The alleged disincentives created by generous public assistance programs are common fodder for political debate. However, there appears to be limited empirical support for these statements. This review of relevant literature attempts to aggregate current knowledge of incentives in the Temporary Assistance for Needy Families program. Results indicate that recipients in states with relatively lenient programs are more likely to achieve long-term financial independence and maintain strong family ties. It is argued that the most successful programs are those incorporating a person-inenvironment perspective.
\end{abstract}

Hamilton, L. (2016). "Incentives in the Temporary Assistance for Needy Families Program: A Review of the Literature." Poverty and Public Policy, Volume 8 : Issue 2, June 2016: pages 141-149. doi:10.1002/pop4.134. Published by Wiley Periodicals, Inc. Version of Record available at: http://onlinelibrary.wiley.com/doi/10.1002/pop4.134/full 


\title{
Incentives in the Temporary Assistance for Needy Families Program: A Review of the Literature
}

\author{
Leah Hamilton \\ Department of Social Work, Appalachian State University, Boone, NC
}

\begin{abstract}
The alleged disincentives created by generous public assistance programs are common fodder for political debate. However, there appears to be limited empirical support for these statements. This review of relevant literature attempts to aggregate current knowledge of incentives in the Temporary Assistance for Needy Families program. Results indicate that recipients in states with relatively lenient programs are more likely to achieve long-term financial independence and maintain strong family ties. It is argued that the most successful programs are those incorporating a person-inenvironment perspective.
\end{abstract}

KEY WORDS: Temporary Assistance for Needy Families, welfare, incentives

Incentives in Public Assistance: A Review of the Literature

The Personal Responsibility and Work Opportunity Reconciliation Act of 1996 was passed with the intention of encouraging workforce participation, strengthening families, and removing incentives for long-term dependency. These reforms, which largely consisted of greater limitations on eligibility, appear to be centered within classical economic theory in which generous benefits are believed to encourage dependency and disincentivize work. Very little research, however, has established whether these new restrictions have created the intended incentives and changed recipient behavior. The current study seeks to provide a better understanding of the true incentives created by welfare reform via a review of relevant research. Further, the person-in-environment perspective (Barker, 2003) will be proposed as an alternative theoretical framework in which to analyze the behavior of welfare recipients.

\section{Literature Review}

Temporary Assistance for Needy Families (TANF) provides cash transfers to low-income families and is the program most often evoked by the term "welfare" in the United States. The current TANF program is an evolution (or a devolution, 
depending on one's political leanings) of the New Deal-era Aid to Dependent Children (ADC) program. ADC gave way to Aid to Families with Dependent Children (AFDC) in 1950, with the intention of including aid to parents (Jansson, 2014). Critics of AFDC "argued that entitlement to cash assistance and related benefits encouraged dependence on government aid [and] provided a disincentive to work" (Ridzi \& London, 2006, p. 725). The availability of cash assistance in addition to Food Stamps, Medicaid, and housing assistance may have indeed outweighed the low-wage, low-benefit work awaiting families who left the program (Cancian, Meyer, \& Caspar, 2008). Further, critics worried that the program discouraged the formation of two-parent families if two incomes were still not sufficient to compensate for the loss of benefits.

These criticisms paved the way for passage of the Personal Responsibility and Work Opportunity Reconciliation Act of 1996 (PRWORA, 1996) in which AFDC was replaced by TANF with the intention of "ending welfare as we know it" (Jansson, 2014). The act's main purposes (enumerated below) are explicit.

The purpose of this part is to increase the flexibility of states in operating a program designed to

1. Provide assistance to needy families so that children may be cared for in their own homes or in the homes of relatives.

2. End the dependence of needy parents on government benefits by promoting job preparation, work, and marriage.

3. Prevent and reduce the incidence of out-of-wedlock pregnancies and establish annual numerical goals for preventing and reducing the incidence of these pregnancies.

4. Encourage the formation and maintenance of two-parent families (42 USC § 601).

To meet these goals, the new program implemented a five-year lifetime limit and required that all recipients work or engage in work-related activities. While AFDC was an entitlement program (meaning that any applicant meeting eligibility criteria was entitled to benefits), TANF became a block grant to states, with incentives for increasing employment and marriage (Ridzi \& London, 2006).

While the intended incentives of TANF appear to be based in a classical economic model of rationality (i.e., generous benefits encourage dependency and restrictive benefits encourage independence), social workers have long advocated for a person-in-environment perspective when analyzing human service delivery (Barker, 2003). This perspective argues that individual choices must be understood within the environmental context of one's family, community, and larger economic and policy structures. It also requires that human service delivery take into account the client's personal experiences and abilities. For example, gainful employment may be difficult to maintain for a client with insufficient education, disabilities, domestic abuse, or caregiving responsibilities. These challenges might be exacerbated by economic conditions such as a recession. This orientation lends itself to a more nuanced understanding of individual behavior in public assistance programs.

A great deal of research has evaluated macro-level outcomes for the TANF program, but few studies have investigated decision making on the individual 
level, as advocated by the person-in-environment perspective. The current study attempts to aggregate the existent research and provide a better understanding of the actual incentives created for TANF recipients within the relevant (see Methodology) literature.

\section{Methodology}

The primary author and a graduate assistant utilized three search engines (Academic One File, JSTOR, and Academic Search Complete) to identify peerreviewed, empirical articles including the terms "incentive" and "Temporary Assistance to Needy Families" in all text. This search resulted in 817 articles across the three search engines. Articles written before 1996 or outside of the United States were then eliminated. These two criteria aided in identifying articles whose primary aim was to analyze the American TANF program, which was first initiated in 1996. Some articles met the above criteria, but the author's discussion of incentives was not a direct result of the article's empirical findings. Such articles were also eliminated. This process resulted in a total of 12 articles that were appropriate for the purposes of this review (see the appendix).

A qualitative content analysis (Hsiu-Fang Hsieh \& Shannon, 2005) was used to analyze themes related to incentives in the TANF program. Data collection and analysis involved a constructivist (Rodwell, 1998), qualitative design. Constructive research is proposed as an alternative to traditional, positivist inquiry. Positivists assume that there exists an absolute reality, and the researcher is in pursuit of absolute truth. Constructivism argues that even if such an absolute reality did exist, the limitations of human understanding make such knowledge unattainable (Rodwell, 1998). For example, the process of determining whether an article does or does not make inferences regarding incentives is inherently biased by the researcher's personal perspective.

To improve trustworthiness, both researchers independently coded each article's conclusions regarding incentives. Emergent themes (Charmaz, 2006) were independently identified, also known as open coding (Berg \& Lune, 2011). These themes were then compared for inter-rater reliability. While few differences emerged between reviewers, these were negotiated through discussion. Finally, axial coding was employed to establish larger themes emerging from the research (Strauss \& Corbin, 1990). This process revealed three themes that are closely related to TANF's intended outcomes of work, family formation, and indepen- dence, but in ways that may be surprising. See Table 1 for a summary of these findings.

\section{Findings}

\section{Work}

Regarding work, four of the studies (Cancian, Meyer, \& Wu, 2005; Connolly \& Marston, 2005; Larrison, Nackerud, \& Risler, 2001; Seefeldt \& Orzol, 2005) 
Table 1. Summary of Findings

\begin{tabular}{|c|c|c|}
\hline Theme & More Successful Changes & Less Successful Changes \\
\hline Work & $\begin{array}{l}\text { - States with generous work require- } \\
\text { ments (more work exemptions, fewer } \\
\text { required working hours, etc.) see } \\
\text { higher wages and more health benefits } \\
\text { for TANF leavers (Lim, Coulton, \& } \\
\text { Lalich, 2009) }\end{array}$ & $\begin{array}{l}\text { - TANF work requirements less success- } \\
\text { ful in moving those without a high } \\
\text { school education to work than AFDC } \\
\text { (Cancian, Meyer, \& Wu, 2005; Con- } \\
\text { nolly \& Marston, 2005) }\end{array}$ \\
\hline \multirow[t]{3}{*}{ Family } & $\begin{array}{l}\text { - Diversion payments reduce abortion } \\
\text { rates (Snarr \& Edwards, 2009) }\end{array}$ & $\begin{array}{l}\text { - Family caps not associated with changes } \\
\text { in recipient birth rates (Wallace, 2009) }\end{array}$ \\
\hline & $\begin{array}{l}\text { - Requiring teen parents to live with a } \\
\text { guardian and attend school associated } \\
\text { with fewer subsequent births (Lopoo } \\
\text { \& DeLeire, 2006) }\end{array}$ & $\begin{array}{l}\text { - TANF restrictions discourage mar- } \\
\text { riage (Cherlin \& Fomby, 2004) }\end{array}$ \\
\hline & $\begin{array}{l}\text { - Passing child support payments on to } \\
\text { mothers associated with faster paternity } \\
\text { establishment and higher rates of pay- } \\
\text { ment (Cancian, Meyer, \& Caspar, 2008) }\end{array}$ & $\begin{array}{l}\text { - Reduced TANF payments are associ- } \\
\text { ated with increased foster care case- } \\
\text { loads (Swann \& Sylvester, 2006) }\end{array}$ \\
\hline Independence & & $\begin{array}{l}\text { - Onerous application process creates } \\
\text { deterrent for otherwise eligible fami- } \\
\text { lies and increased utilization of other } \\
\text { programs (Cancian et al., 2005; Ridzi } \\
\text { \& London, 2006) }\end{array}$ \\
\hline
\end{tabular}

discussed the need for TANF work requirements to better account for personal and educational barriers. For example, Connolly and Marston (2005) and Cancian et al. (2005) both discovered that post-1996 TANF work requirements were more effective in moving high school graduates to employment than those without a diploma. Connolly and Marston (2005) found that educational supports in the pre-TANF Aid to Families with Dependent Children program were much more effective in moving recipients who had not yet finished high school to eventual independence.

Seefeldt and Orzol (2005) and Larrison et al. (2001) both described the multiple and overlapping personal barriers among some recipients that made work requirements and time limits impractical. These barriers include "persistent maternal and child health problems, persistent domestic violence, lack of a partner, low levels of education and increases in the number of children" (Seefeldt \& Orzol, 2005, p. 226). Larrison et al. (2001) suggest that reforms in Social Security Disability Insurance could better serve many TANF families who face multiple physical and mental health barriers.

Further, states with the most generous work requirements experienced higher rates of long-term success among recipients (Connolly \& Marston, 2005; Lim, Coulton, \& Lalich, 2009). TANF families in states that granted more work exemptions, had fewer required work hours, and had lower financial sanctions left TANF with higher wages and were more likely to find a job with employerprovided health care than recipients in states with more stringent requirements 
(Lim et al., 2009). The authors suggest that lenient work requirements may give recipients more time to look for high-quality employment and result in greater long-term success than the national population of TANF leavers, who often find low-quality jobs.

\section{Family}

TANF incentives are also related to family connectedness and family planning. For example, Snarr and Edwards (2009) found that diversion payments (lump sums in lieu of TANF) are associated with reduced rates of abortion among low-income single mothers. Some states have attempted to limit childbearing among TANF mothers "by denying additional cash assistance to recipients who have children while on welfare" (Wallace, 2009, p. 73), also known as family caps. These caps do not appear to have achieved the desired effect, as they are unrelated to changes in birth rates among recipients (Wallace, 2009). Conversely, post-1996 rules requiring teen parents to live with a guardian and attend school are associated with decreased teen birth rates (Lopoo \& DeLeire, 2006).

Welfare rules are further influential in connectedness among the adults in a family. While some state TANF agencies retain child support payments for administrative costs, those passing the payments on to the mother and child experience faster paternity establishment and higher rates of payment (Cancian et al., 2008). TANF receipt also appears to influence a mother's decision to marry, but not necessarily to cohabitate (Cherlin \& Fomby, 2004). The authors postulate that marriage is likely a financial decision for a mother, and she must weigh whether a potential partner has sufficient income stability to risk the loss of assistance.

Finally, post-1996 public assistance appears to have created a ripple effect in the child welfare system. Reduced TANF payments are associated with increased foster care caseloads, possibly due to increased family strain and maltreatment (Swann \& Sylvester, 2006). In addition, relative caregivers are more likely to become formally involved with child welfare (in order to access foster care funds) when TANF payments are unavailable (Swann \& Sylvester, 2006).

\section{Independence}

The final emergent theme is related to the program's stated goal of increased financial independence. The examined literature suggests that reductions in TANF caseloads (independence from the program) may not be synonymous with total financial independence. For example, two studies (Cancian et al., 2005; Ridzi \& London, 2006) discovered that an onerous application process was creating an unintended deterrent for otherwise eligible families. Restrictive TANF work requirements were also related to increased utilization of other programs, such as Food Stamps (Cancian et al., 2005). In other words, families in need were not necessarily "rehabilitated" by TANF, but instead diverted to other sources of help. 


\section{Discussion}

The methodology of this study presents multiple limitations. Primarily, restricting the sample to those articles that used the term "incentive" may have eliminated appropriate literature that employed synonyms to "incentive." However, including other terms may have created an unmanageable sample size for the qualitative design. Further, this study only examined articles related to one specific program (TANF). There are several other programs such as Disability Insurance, Unemployment Insurance, and the Earned Income Tax Credit that have been similarly criticized for incentivizing dependency. Future research ought to employ a similar methodology with these programs. Still, the use of a systematic search process and the use of transparent, reproducible analysis methods are significant strengths of this work.

The research described here suggests that the intended incentives of the Personal Responsibility and Work Opportunity Reconciliation Act of 1996 may have been based in a whole or partial misunderstanding of personal decision making in regard to work, family, and independence. For example, a woman's decision to have children appears to be unrelated to TANF benefits (Wallace, 2009). Further, as noted by Cherlin and Fomby (2004), a recipient's decision to marry may be influenced by larger economic structures, such as the availability of well-paid work for a potential spouse. A systematic review of welfare-to-work programs in the United States similarly found that outcomes for TANF recipients were only slightly more positive than those in a comparison group (Smedslund et al., 2006).

Among the examined literature, the most successful programs appear to be those that operate from a person-in-environment perspective (Barker, 2003). Those programs that supported a pregnant mother's short-term financial needs (Snarr \& Edwards, 2009), provided greater flexibility for job seekers (Connolly \& Marston, 2005; Lim et al., 2009), allowed fathers to support their children (Cancian et al., 2008), and required teen mothers to live with a guardian (Lopoo \& DeLeire, 2006) experienced the most positive outcomes among recipients. Further, several of the studies discussed the need for the TANF program to better understand the complex lives of welfare applicants.

These personal perspectives can be difficult to understand when programs such as TANF are studied solely in large-scale quantitative approaches. This is particularly apparent in studies such as Snarr and Edwards (2009), who discovered complex results when analyzing countrywide data over the course of 13 years (1990-2003). They find that "diversion payments to low-income mothers lower abortion incidence" (p. 575). Conversely, they also report that the combined availability of diversion payments and TANF eligibility increased abortion rates among childless women (Snarr \& Edwards, 2009). These results became further complicated by the particular trimester of pregnancy during which women applied for assistance. The lives and decisions of these women (and all of the recipients described here) would be better understood with a mixed methodological design that includes smaller-scale, qualitative inquiry. 
Previous research further supports the notion that overly simplistic beliefs regarding disincentives for independence created by generous public assistance are counterproductive. Nam (2008), for example, discovered that increased eligibility (via maximum allowable financial assets) in the TANF program was associated with increased savings rates among all low-income families, not just those receiving assistance. When low-income families save, they are able to build their own financial safety net and become less dependent upon public assistance over time (Sherraden, 1991). This suggests that restrictive eligibility might actually create disincentives for independence when a family fears that any small increase in assets might make them ineligible for assistance but would not be enough to sustain them through a major emergency (job loss, etc.). Hamilton, AlexanderEitzman, and Royal (2015) confirm that increases in allowable financial assets do not appear to be associated with greater utilization of public assistance. It is therefore proposed that TANF policies that create greater flexibility for individual circumstances and fewer eligibility restrictions will likely be more effective in creating stable, self-sufficient American families.

\section{References}

Barker, R. L. (2003). The social work dictionary (5th ed.). Washington, DC: NASW Press.

Berg, B. L., \& H. Lune. (2011). Qualitative research methods for the social sciences (8th ed.). Boston: Pearson.

Cancian, M., D. R. Meyer, \& E. Caspar. (2008). “Welfare and child support: Complements, not substitutes." Journal of Policy Analysis and Management, 27(2), 354-375.

Cancian, M., D. R. Meyer, \& C.-F. Wu. (2005). “After the revolution: Welfare patterns since TANF implementation." Social Work Research, 29(4), 199-214. doi: 10.1093/swr/29.4.199

Charmaz, K. (2006). Constructing grounded theory: A practical guide through qualitative analysis (1st ed.). Thousand Oaks, CA: Sage.

Cherlin, A. J., \& P. Fomby. (2004). "Welfare, work, and changes in mothers' living arrangements in low-income families." Population Research and Policy Review, 23(5/6), 543-565.

Connolly, L. S., \& C. E. Marston. (2005). “Welfare reform, earnings, and incomes: New evidence from the Survey of Program Dynamics." Contemporary Economic Policy, 23(4), 493-512. doi: 10.1093/ cep/byi037

Hamilton, L., B. Alexander-Eitzman, \& W. Royal. (2015). "Shelter from the storm: TANF, assets and the Great Recession." SAGE Open, 5(1), 1-6. http://doi.org/10.1177/2158244015572487

Hsieh, H., \& S. E. Shannon. (2005). “Three approaches to qualitative content analysis." Qualitative Health Research, 15(9), 1277-1288. http:/ / doi.org/10.1177/1049732305276687

Jansson, B. S. (2014). The reluctant welfare state: Engaging history to advance social work practice in contemporary society (8th ed.). Belmont, CA: Cengage Learning.

Larrison, C. R., L. Nackerud, \& E. Risler. (2001). “A new perspective on families that receive Temporary Assistance for Needy Families (TANF)." Journal of Sociology E Social Welfare, 28(3), 49-69.

Lim, Y., C. J. Coulton, \& N. Lalich. (2009). "State TANF policies and employment outcomes among welfare leavers." Social Service Review, 83(4), 525-555.

Lopoo, L. M., \& T. DeLeire. (2006). “Did welfare reform influence the fertility of young teens?" Journal of Policy Analysis and Management, 25(2), 275-298. 
Nam, Y. (2008). “Welfare reform and asset accumulation: Asset limit changes, financial assets, and vehicle ownership." Social Science Quarterly, 89(1), 133-154.

Personal Responsibility and Work Opportunity Reconciliation Act, 42 USC $§ 601$ (1996).

Ridzi, F., \& A. S. London. (2006). “It's great when people don't even have their welfare cases opened': TANF diversion as process and lesson." Review of Policy Research, 23(3), 725-743. doi:10.1111/ j.1541-1338.2006.00226.x

Rodwell, M. K. (1998). Social work, constructivist research. New York: Taylor \& Francis.

Seefeldt, K. S., \& S. M. Orzol. (2005). “Watching the clock tick: Factors associated with TANF accumulation." Social Work Research, 29(4), 215-229. doi:10.1093/swr/29.4.215

Sherraden, M. (1991). Assets and the poor: A new American welfare policy. New York: M. E. Sharpe.

Smedslund, G., T. K. Dalsbo, K. B. Hagen, T. Johme, M. G. Rud, A. Steiro, \& A. Steiro. (2006). “Work programmes for welfare recipients: A systematic review." Campbell Systematic Reviews, 2(9). Retrieved from http:/ / campbellcollaboration.org/lib/project/18/

Snarr, H. W., \& J. A. Edwards. (2009). “Does income support increase abortions?" Social Choice and Welfare, 33(4), 575-599. doi:10.1007/s00355-009-0380-x

Strauss, A., \& J. M. Corbin. (1990). Basics of qualitative research: Grounded theory procedures and techniques. Thousand Oaks, CA: Sage.

Swann, C. A., \& M. S. Sylvester. (2006). "The foster care crisis: What caused caseloads to grow?" Demography, 43(2), 309-335.

Wallace, G. L. (2009). “The effects of family caps on the subsequent fertility decisions of never-married mothers." Journal of Population Research, 26(1), 73-101.

\section{Appendix}

\section{Articles Meeting Methodology Criteria}

Cancian, M., D. R. Meyer, \& E. Caspar. (2008). “Welfare and child support: Complements, not substitutes." Journal of Policy Analysis and Management, 27(2), 354-375.

Cancian, M., D. R. Meyer, \& C.-F. Wu. (2005). “After the revolution: Welfare patterns since TANF implementation." Social Work Research, 29(4), 199-214. doi:10.1093/swr/29.4.199

Cherlin, A. J., \& P. Fomby. (2004). "Welfare, work, and changes in mothers' living arrangements in low-income families." Population Research and Policy Review, 23(5/6), 543-565.

Connolly, L. S., \& C. E. Marston. (2005). “Welfare reform, earnings, and incomes: New evidence from the Survey of Program Dynamics." Contemporary Economic Policy, 23(4), 493-512. doi:10.1093/cep/byi037

Larrison, C. R., Nackerud, L., \& Risler, E. (2001). “A new perspective on families that receive Temporary Assistance for Needy Families (TANF)." Journal of Sociology \& Social Welfare, 28(3), 49-69.

Lim, Y., C. J. Coulton, \& N. Lalich. (2009). "State TANF policies and employment outcomes among welfare leavers." Social Service Review, 83(4), 525555.

Lopoo, L. M., \& T. DeLeire. (2006). “Did welfare reform influence the fertility of young teens?" Journal of Policy Analysis and Management, 25(2), 275-298. 
Ridzi, F., \& A. S. London. (2006). “'It's great when people don't even have their welfare cases opened': TANF diversion as process and lesson." Review of Policy Research, 23(3), 725-743. doi:10.1111/j.1541-1338.2006.00226.x

Seefeldt, K. S., \& S. M. Orzol. (2005). "Watching the clock tick: Factors associated with TANF accumulation." Social Work Research, 29(4), 215-229. doi:10.1093/swr/29.4.215

Snarr, H. W., \& J. A. Edwards. (2009). "Does income support increase abortions?" Social Choice and Welfare, 33(4), 575-599. doi:10.1007/s00355-009-0380$x$

Swann, C. A., \& M. S. Sylvester. (2006). "The foster care crisis: What caused caseloads to grow?" Demography, 43(2), 309-335.

Wallace, G. L. (2009). "The effects of family caps on the subsequent fertility decisions of never-married mothers." Journal of Population Research, 26(1), 73-101. 